\title{
Antrolana lira, a new genus and species of troglobitic cirolanid isopod from Madison Cave, Virginia
}

Bу Тномаs E. Bowman, Smithsonian Institution, Washington, D.C. U.S.A.

With plates $50(1)-57(8)$

The 6 species of troglobitic cirolanid isopods known in the western hemisphere are distributed in Cuba (1 species), Mexico (4 species) and Texas (1 species). All are believed to be descendants of marine ancestors from the Gulf of Mexico (Bolivar y Pieltain, 1950). The discovery of a cirolanid from a cave in the Appalachian Valley of Virginia adds a seventh species, noteworthy not only because it represents a new genus, but also because of the considerable distance by which it is separated from the other species. In addition to a description of the new species, I give below a redescription of Cirolanides texensis, the only other troglobitic cirolanid known from the United States. Rioja (1953) correctly pointed out the need for a reexamination of Cirolanides; this reexamination was necessary to determine whether the species from Virginia and $C$.texensis are generically distinct.

I am grateful to Dr. Thomas C. Barr, University of Kentucky, for making the specimens available to me, and to Mr. John R. Holsinger of the same institution for information about the type locality.

\section{Antrolana, new genus}

Body flattened, compact. Anterior margin of head produced as shelf beyond bases of antennae 1 and 2 ; somite of maxilliped indicated by ventrolateral groove. Eyes and body pigment absent. Pleonites 1-5 distinct; lateral margins of pleonite 5 covered by pleonite 4. Antenna 2 much longer than antenna 1; peduncle of 6 segments (first rudimentary), flagellum with numerous segments. Inner ramus of maxilla 1 with 3 strong plumose setae. Maxilliped with single coupling spine. Pereopod 1 prehensile, with strong propodus; pereopods 2-7 slender, ambulatory, increasing in length posteriorly. No propodial organ in pereopods 2-3. Pleopod 1 not heavily sclerotized. Both rami of pleopods 1-2 natatory, fringed with plumose setae, undivided. Exopod of pleopods 3-5 fringed with setae, divided by transverse suture; endopods undivided, fleshy, without marginal setae, with transverse pleats. Uropods with well developed rami; inner distal angle of peduncle moderately produced. Type-species, Antrolana lira new species. 
The generic name is derived from the Greek "antron," a cave, plus (Ciro)lana. Gender, feminine.

\section{ANTROLANA LIRA, new species}

Figures 1-42

Length up to $12 \mathrm{~mm}$, about 3 times the width. Head rounded in front, posterolateral corners covered by pereonite 1. Frontal lamina a narrow carina, not strongly projecting, not bifid. Clypeus obtusely triangular. Mandibular margin of labrum concave. Pereonite 1 much longer than other pereonites; pereonites 2-4 subequal; pereonites 5-7 subequal, longer than pereonites $2-4$. Coxal plates with low carinae; posteroventral corners moderately produced on pereonites $4-7$. Penis short, blunt (specimens may not be fully sexually mature). Pleonite 1 partly covered by pereonite 7; posterolateral margins of pleonites 1-4 angularly produced. Telson subpentagonal, widest at base, lateral margins converging slightly; posterior margin broadly angular, setose, with 8-10 spines in central part.

Antenna 1 short, reaching slightly beyond posterior margin of head. Peduncle 3-segmented, relative length of segments shown in figure 7 . Flagellum 12-18-segmented (more segments in larger specimens); segment 1 longer than others; pair of aesthetases present on anterodistal margin of all but proximal 2-3 segments; alternate segments have pair of spines proximal to aesthetases and single spine posterior to them near distal margin (fig. 9). Antenna 2 long, reaching middle of pereonite 6 . Peduncle 6-segmented; first segment very small; relative lengths of peduncular segments shown in fig. 8. Flagellum of 38-42 segments, with fewer segments in smaller specimens; armature of segments similar on ventral surface (fig. 11); dorsally, segments with 2 patterns of setal armature which alternate through most of flagellum (fig. 12).

Mandibles asymmetrical; left incisor overlapping right; teeth of left incisor less deeply divided than right. Lacinia mobilis present on both mandibles, bearing about 13 curved marginal spines; molar typical for Cirolanidae; segment 3 and distal 0.4 of segment 2 of palp bearing plumose setae. Exopod of maxilla 1 with 11 stout unarmed spines, 7 external and 4 internal, and 3 setae; external spines arranged in 2 groups separated by rather large gap; proximal group of 4 spines increasing in length distally, distal group of 2 small and 1 large apical spine; internal spines large, proximal 3 bent inward; setae arranged as shown in fig. 19. Endopod of maxilla 1 hatchet-shaped, outer distal angle almost square; inner margin with 3 plumose spines, a slender 
seta at base of distal spine, and a shorter seta on distal margin near distal spine. Maxilla 2 and maxilliped as in figs. 21-24.

Pereopod 1 stout; posterior margins of merus and propodus each armed with 5 stout spines; posterior margin of propodus concave, bearing distally a spine on lateral surface, 3 setae at base of spine (fig. 28), and 4 medial setae (fig. 27); "dactyl organ" at distal end of dactyl composed of 6 setae. Dactyl organ of pereopods 2-7 with 5 setae.

Endopod of pleopod 1 about half as wide as exopod; medial margin straight, thickened. Processus masculina of male pleopod 2 inserted near base of endopod, slightly longer than endopod, gently curved outward; lateral part of apex produced into point, medial to which is inserted plumose seta. Endopods of pleopods 3-5 narrower and shorter than exopods, with pleats as shown in figs. 38-40. Peduncle of uropod bearing setae on distal half of medial margin. Exopod about 5 times as long as wide; medial margin and apex armed with setae; 4 spines on lateral margin and 3 at apex. Endopod pyriform, about 3 times as wide as exopod, with 7-8 marginal spines distally; medial margin and distal part of lateral margin with setae.

Types. Male holotype, 12 mm, USNM 110783, collected 23 August 1958 in Madison Cave, Augusta Co., Virginia, by Thomas C. Barr, and 6 paratypes, also collected from Madison Cave by Dr. Barr 23 August 1958 (USNM 110785) and 2 January 1959 (USNM 110784).

The following information on Madison Cave was kindly sent to me by Mr. John R. Holsinger, University of Kentucky:

"Madison Cave is located in Augusta County, Virginia, just west of the South Fork of the Shenandoah River and 0.2 miles south of Grottoes. It is also 0.2 miles north of the rather well known Grand Caverns. The isopods were collected by Barr from one of two deep pools several hundred feet inside of the cave. The specimens were sighted in the shallow portion of the pool adjacent to its bank. Immediately beyond this point the pool becomes deep rather rapidly. Both of these pools appear to be flooded, crevice-like passages and are only accessible on the side facing the dry passageways. Their extent on the side opposite the passageways is unknown. The cave itself is not large and probably contains less than 1000 feet (if that much) passage. It was once commercial, but this project was abandoned long ago. Several years ago I went there in hopes of finding additional cirolanids, but was unable to find any specimens in either pool."

Dr. Baar (in litt. 10 Dec. 1963) has added the following: "The specimens were resting on the silt and talus just below the surface of the water. A person standing at the edge of the water causes the talus to creep, which apparently disturbed the isopods. They swam upward 
rather rapidly, almost to the surface, then slowly floated downward. Only a few specimens, near the edge, were within reach of a net, the remainder floating down into inaccessible portions of the pool."

The name "Madison Cave" was used for 2 caves in the vicinity of Grand Caverns by McGill (1946): the cave in which Antrolana was discovered and a second cave, the entrance to which is about $450 \mathrm{~m}$ south of the entrance to Grand Caverns. According to Mr. Holsinger, the latter cave is now called "Fountain Cave." Madison Cave, Fountain Cave, and Grand Caverns, as well as Shenandoah Caverns in Shenandoah County, Virginia, are in Conococheague limestone, a Cambrian formation consisting essentially of irregularly interbedded gray to blue limestone, and dolomite with some beds of sandstone in the lower part (McGill, 1933).

The specific name "lira," proposed as a noun, is from the Latin noun meaning "the earth thrown up between 2 furrows," and refers to the pleats on the endopods of pleopods $3-5$.

\section{Cirolanides Benedict, 1896}

Similar to Antrolana except: Lateral margins of pleonite 5 not covered by pleonite 4. Maxilliped with 2 coupling spines. Exopod of pleopod 2 divided by transverse suture. Endopods of pleopods 3-5 2-segmented, moderately thick and fleshy in pleopod 3, markedly so in pleopods 4-5. Type-species, by monotypy, Cirolanides texensis Benedict, 1896.

\section{CIROLANIDES TEXENSIS Benedict}

Figs. 43-60

Cirolanides texensis Benedict, 1896, p. 616. - Richardson, 1900, p. 217; 1905, pp. 120-123, figs. 103-106. - Ulrich, 1902, pp. 88-90, pl. 15 - Eigenmann, 1909, p. 201. - Ortmann, 1918, p. 841, fig. 1304. - Chappuis, 1927, p. 71. - Van Name, 1936, pp. 427-428, fig. 265. - Pennak, 1953, p. 431, fig. 270 A. - Mackin, 1959, p. 873, fig. 31. 3 b.

Length up to $17 \mathrm{~mm}$. Head more broadly rounded than in Antrolana lira; anterior margin produced as shelf beyond bases of antennae 1 and 2. Frontal lamina a narrow carina, strongly projecting. Pleopods occupying about central $2 / 3$ of pleon width. Telson broadly rounded, posterior margin armed with about 10 short fine setae. Antennae 1 and 2 shorter and with fewer flagellar segments than in specimens of Antrolana lira of comparable size; antenna 2 reaching posterior margin of pleonite 4. Mandible very similar to that of Antrolana. Maxilla 1 as in Antrolana, except inner ramus rounded on outer margin, not hatchet-shaped. Maxilliped with 2 coupling spines. 
Posterior margin of propodus of pereopod 1 nearly straight, armed with 3 spines; merus with 2 spines on posterior margin and 1 on medial surface. Dactyl organ present on pereopods $1-7$.

Endopod of pleopod 1 about $1 / 3$ as wide as exopod, medial margin straight, thickened. Processus masculina of male pleopod 2 inserted near base of endopod, longer and more strongly curved than in Antrolana; apex round, unarmed. Mediodistal corner of peduncle of uropod less produced than in Antrolana; exopod about 8 times as long as wide, with cluster of long setae at apex; endopod much narrower than in Antrolana, about 3 times as wide as exopod, with cluster of long setae and 2 spines at apex.

Distribution. Caves and underground waters of south central Texas, from the vicinity of Del Rio, Val Verde County, in the west to San Marcos, Hays County, in the east. The U.S. National Museum has specimens from the following 7 caves in this region, in addition to the type locality, an artesian well at San Marcos: Hays Co.: Ezell's Cave; Val Verde Co.: Sally Cave, Diablo Cave $(24 \mathrm{~km}$ NW of Del Rio), Little Diablo Cave; Real Co.: Bonner Fallout Shelter Cave; Edwards Co.: Devil's Sinkhole, (Rock Springs); Uvalde Co.: Indian Creek Cave. Most of these records are due to the efforts of Mr. James Reddell of the Texas Speleological Survey, and records from other localities in Texas are anticipated from the continuing collecting activities of the Survey.

\section{Remarks on Relationships}

Of the known genera of troglobitic Cirolanidae, only Cirolanides and Typhlocirolana have pereopod 1 prehensile and pereopods 2-7 ambulatory. Cirolanides appears to be closest to Antrolana, but differs in the unique pleopod segmentation and in having the lateral margins of pleonite 5 not covered by pleonite 4. In Typhlocirolana, from the Mediterranean region, the body is relatively longer and narrower, more rounded in cross section, and the segments are rather loosely articulated. Pleonite 1 is much longer than the other pleonites, and pereopods 2 and 3 , at least in one sex, have a characteristic "propodial organ." An excellent account of the morphology of Typhlocirolana is given by Racovitza (1912).

The following key separates the known genera of troglobitic Cirolanidae of the Western Hemisphere, with the exception of Conilera stygia Packard (1900), which was quite inadequately described by Packard and has not been rediscovered. I have raised Speocirolana Bolivar y Pieltain (1950) from a subgenus of Cirolana to genus because of differences in the structure of the pleopods and the prehensile 
pereopods 1-3. Monod (1930) called attention to the importance of the pleopods as a taxonomic character in the Cirolanidae; in the typespecies of Cirolana, C.cranchi Leach, the endopods of pleopods 1-4 are fringed with setae, whereas in Speocirolana, as in Antrolana, only the endopods of pleopods 1-2 are setose.

1. None of pereopods clearly prehensile $\ldots \ldots \ldots \ldots \ldots \ldots \ldots \ldots 2$

Pereopod 1 prehensile, pereopods $2-7$ ambulatory .......... 3

Pereopods 1-3 prehensile, pereopods $4-7$ ambulatory .... Speocirolana.

Bolivar y Pieltain

2. Body able to roll into ball. ............... Creaseriella Rioja

Body not able to roll into ball............. Troglocirolana Rioja

3. Exopod of pleopod 2 and endopods of pleopods $3-5$

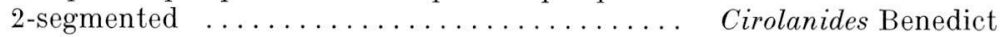

Exopod of pleopod 2 and endopods of pleopods $3-5$

1 -segmented $\ldots \ldots \ldots \ldots \ldots \ldots \ldots \ldots \ldots \ldots \ldots \ldots$ Antrolana new genus

\section{Origin of Antrolana}

The distribution of western hemisphere troglobitic Cirolanidae is shown in pl. 57. The origin from marine ancestors offers no particular problem except in the case of Antrolana. Creaseriella and Troglocirolana inhabit waters that were in communication with the sea during the Cenozoic Era. The localities in which Speocirolana, Conilera stygia, and Cirolanides are found were inundated by the sea during the Late Cretaceous and possibly more recently. The Appalachian Valley, however, is not known to have been close to an arm of the sea since the late Pennsylvanian or early Permian Periods, about 280 million years ago, when lowlands to the west were occasionally invaded by brackish or marine waters. It is taxing credence to suppose that Antrolana (or its direct-line ancestor) is a marine relict of Paleozoic origin. Another possibility is that Antrolana originated at the southern end of the Appalachians as a relict from the Mississippi Embayment in Cretaceous or Cenozoic times and gradually dispersed northward thru subterranean pathways. However, as Dr. Barr points out (in litt., 10 Dec. 1963): "The geologic barriers to northward dispersal from the southern end of the Appalachians are so formidable that it is extremely difficult to believe that subterranean dispersal could have taken place over this distance." The third alternative, which Dr. Barr favors, is migration upstream from the Atlantic coast. This route is physically the easiest, but it would require a freshwater epigean progenitor, in contrast to other troglobitic cirolanids, which are believed to be descended directly from marine ancestors. The third alternative also would place the origin of Antrolana at a considerable distance from that of the other American cave cirolanids. 


\section{SUMMARY}

Antrolana lira, a new genus and species of troglobitic cirolanid isopod, is described from Madison Cave, in the Appalachian Valley of Virginia. The problem of its origin from a marine ancestor is discussed. A supplementary description is given of Cirolanides texensis, and records of its occurrence are given. A key is given to the troglobitic Cirolanidae of the Western Hemisphere, and their known distribution is shown on a map. The subgenus Speocirolana Bolivar y Pieltain is raised to genus.

\section{RÉSUMÉ}

Une espèce d'un genre nouveau d'Isopode troglobie Cirolanide Antrolana lira est décrite de la grotte de Madison (Appalachian Valley, Virginia, U.S.A.). Le problème de ses origines à partir d'un ancêtre marin est discuté. En plus une description est donnée de Cirolanides texensis avec une liste des grottes et sources où on la rencontre.

On y a joint un tableau des Cirolanides troglobies de l'hémisphère Ouest et une carte de leur répartition actuellement connue. -Le sous-genre Speocirolana Bolivar y Pieltain doit prendre rang de genre.

\section{REFERENCES}

Benedict, James E. - 1896: Preliminary descriptions of a new genus and three new species of crustaceans from an artesian well at San Marcos, Texas. Proc. U.S. Nat. Mus. 18 (1087) : 615-617.

Bolivar y Pieltain, C. - 1950: Estudio de una Cirolana cavernicola nueva de la region de Valles, San Luis Potosi, Mexico. Ciencia (Mexico) $10(11-12): 211-218$.

Chappuis, Pierre A. - 1927: Die Tierwelt der unterirdischen Gewässer. Die Binnengewässer 3:1-175.

Eigenmann, Carl H. - 1909: Cave vertebrates of America. A study in degenerative evolution. Carnegie Inst. Washington Publ. 104:1-241.

Maскіл, Јон N. - 1959: Malacostraca: Isopoda, pp. 872-876. In Ward and Whipple's Fresh-Water Biology, second ed., ed. by W.T. Edmondson. New York: John Wiley \& Sons, Inc.

McGill, Willia m M. - 1933: Caverns of Virginia. Bull. Virginia Geol. Surv., State comm. Cons. Develop. 35 (Educ. Ser. No. 1):1-187.

- 1946: Notes on undeveloped caves of Virginia. Bull. Nat. Speleol. Soc. No. $8: 1-7$.

Monod, TheOdore - 1930: Contribution à l'étude des "Cirolanidae». Ann. Sci. Nat., Zool., 10 ser., 13:129-183.

Ortuann, Arnold E. - 1918: Chapter 25, Higher crustaceans (Malacostraca), pp. 828-850. In Henry B. Ward and George C. Whipple, FreshWater Biology, first ed. New York; John Wiley \& Sons, Inc.

Packard, Alpheus S. -1900: A new eyeless isopod crustacean from Mexico. Proc. American Assoc. Adv. Sci. 49:228.

Pennak, Robert W. - 1953: Fresh-water invertebrates of the United States. New York, Ronald Press. 769 pp.

Racovitza, Émile G. - 1912: Cirolanides (première série). Biospeleologia 27. Arch. Zool. Exptl. Gén., 5 ser., 10:203-329, pls. 1-28. 
Richardson, Harriet - 1900 : Synopsis of North-American invertebrates. VIII. The Isopoda. - Part I. Chelifera, Flabellifera, Valvifera. American Naturalist 34 (399): 207-230.

- 1905: A monograph on the isopods of North America. Bull. U.S. Natl. Mus., no. 54:1-727.

Rioja, Enrique - 1953: Estudios carcinologicos. XXX. Observaciones sobre los cirolánidos cavernícolos de México (crustaceos, isópodos). An. Inst. Biol., México 24 (1):147-170.

Ulrich, Carl J. - 1902: A contribution to the subterranean fauna of Texas. Trans. American Microscop. Soc. 23:83-101, pls. 14-18.

Van Name, Willard G. - 1936: The American land and fresh-water isopod Crustacea. Bull. American Mus. Nat. Hist. 71:1-535.

\section{EXPLANATION OF PLATES 50 (1)-57 (8)}

Figs. 1-6. Antrolana lira, new species. 1. Dorsal view; 2. Pereon and pleon, lateral; 3. Head, ventral; 4. Pereonites 4 and 5, ventral; 5. Penis; 6 . Posterior margin of telson, dorsal.

Figs. 7-17. Antrolana lira, new species. 7. Antenna 1, dorsal; 8. Antenna 2, dorsal; 9. Segments 7-8 of antenna 1 flagellum, ventral; 10. Aesthetasc from antenna $1 ; 11$. Segment 7 of antenna 2 flagellum, ventral; 12. Segments 24-25 of antenna 2 flagellum, dorsal; 13. Left mandible; 14 . Lacinia mobilis of left mandible; 15. Distal segment of mandibular palp, flattened; 16. Molar of left mandible; 17. Molar of right mandible.

Figs. 18-24. Antrolana lira, new species. 18. Maxilla 1; 19. Outer ramus of maxilla 1, chewing surface; 20. Part of inner ramus of maxilla 1, enlarged; 21. Maxilla 2; 22. Maxilliped; 23. Maxilliped, inner ramus; 24. Coupling spine of maxilliped.

Figs. 25-34. Antrolana lira, new species. 25. Pereopod 1, medial; 26. Pereopod 1, distal end of dactyl, lateral; 27. Pereopod 1, propodaldactyl juncture, medial; 28. Same, lateral; 29. Pereopod 2, lateral; 30. Pereopod 2, distal end of dactyl, lateral; 31. Pereopod 3, lateral; 32. Pereopod 7; 33. Pereopod 7, distal end of dactyl, lateral; 34. Perepod 7, juncture of dactyl with its spine.

Figs. 35-42. Antrolana lira, new species. 35. Pleopod 1; 36. Pleopod 2, male; 37 . Apex of appendix masculina of male pleopod $2 ; 38$. Pleopod $3 ; 39$. Pleopod 4; 40. Pleopod 5; 41. Left uropod, dorsal; 42. Spine from lateral margin of exopod of uropod.

Figs. 43-50. Cirolanides texensis Benedict. 43. Dorsal view; 44. Pereon and pleon, lateral; 45. Pereonites 4 and 5, ventral; 46. Head, ventral; 47. Telson, dorsal; 48.Penis; 49. Antenna 1; 50. Maxilla 1.

Figs.51-60. Cirolanides texensis Benedict. 51.Antenna 2, peduncle and flagellar segments 1-3; 52. Maxilliped; 53. Pereopod 1, medial; 54.Pereopod 2, medial; 55. Pleopod $1 ; 56$. Pleopod 2, male; 57. Pleopod 3; 58. Pleopod 4; 59. Pleopod 5; 60. Uropod.

Fig.61. Distribution of troglobitic cirolanid isopods in the Western Hemisphere. 1. Antrolana lira; 2. Cirolanides texensis; 3. Conilera stygia; 4. Speocirolana peleazi and S.bolivari; 5.Creaseriella anops; 6.Troglocirolana cubensis. 
SPELEOLOGY, I

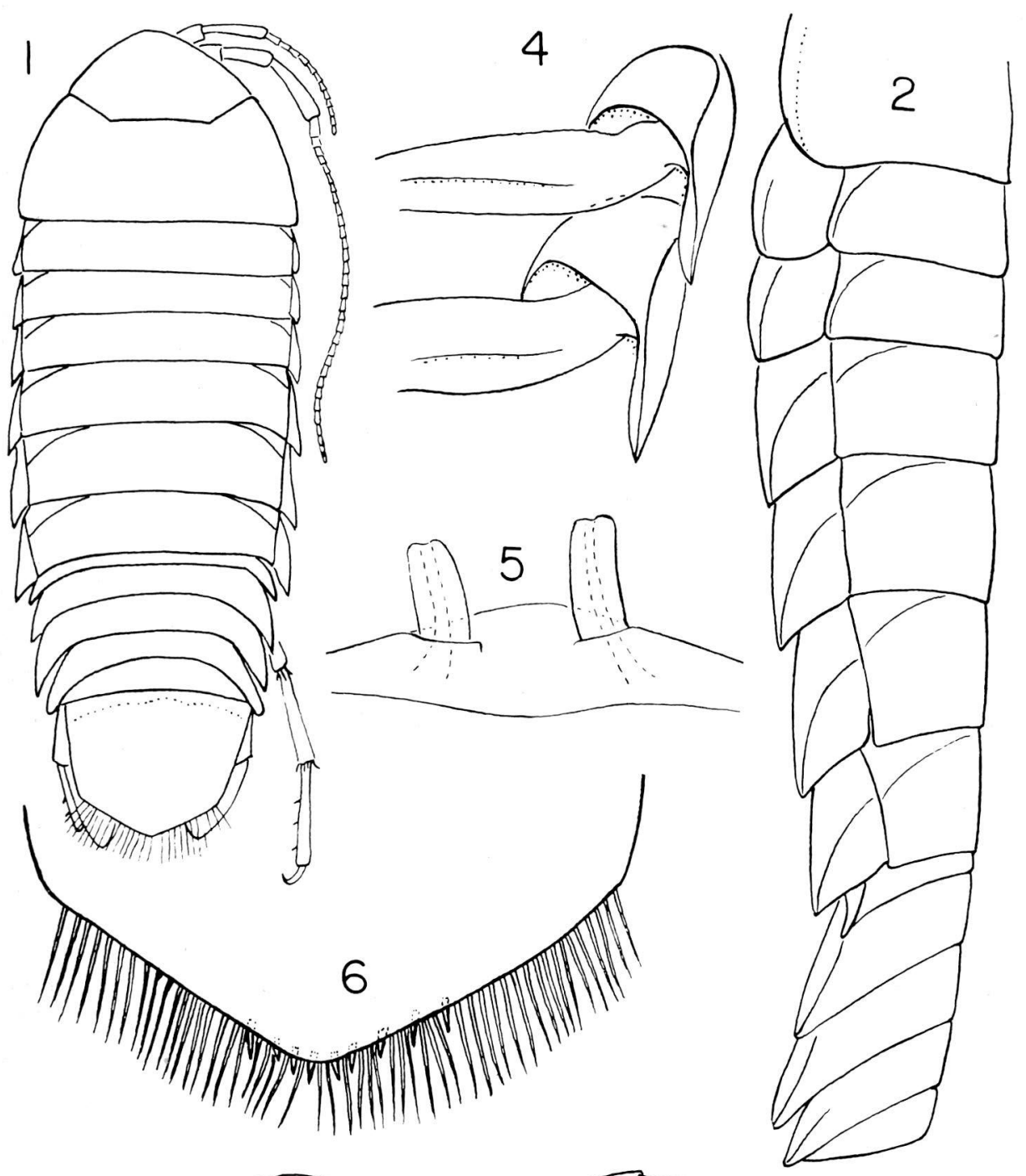

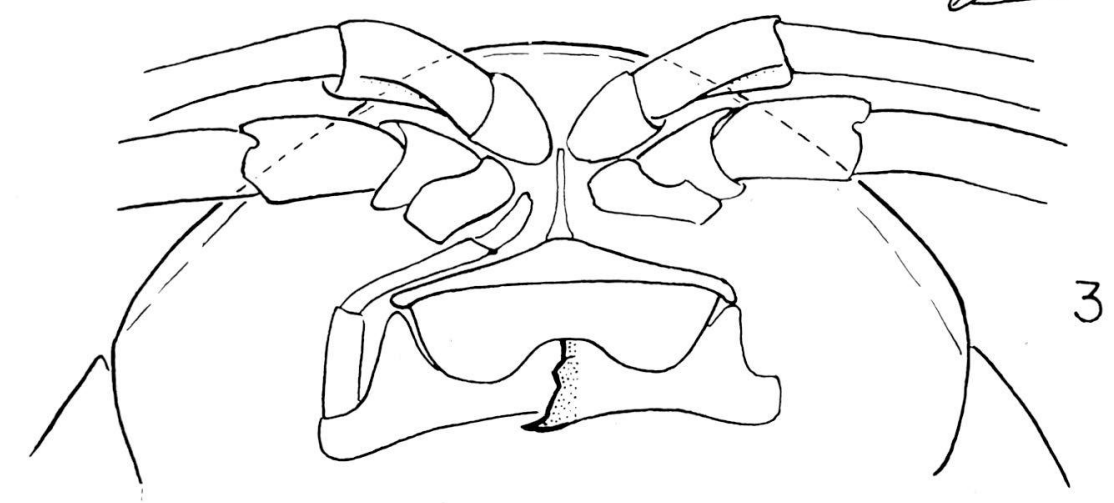




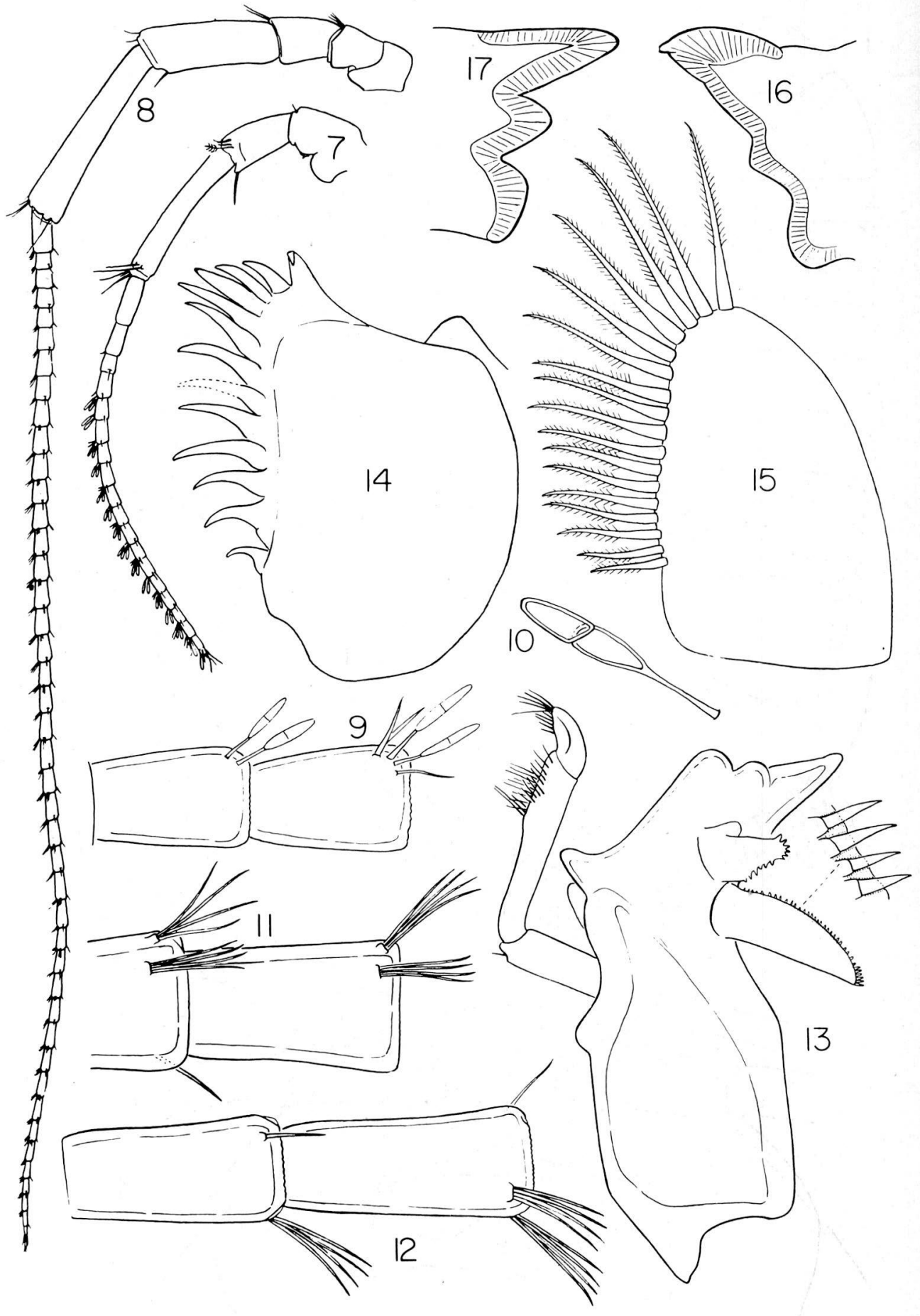




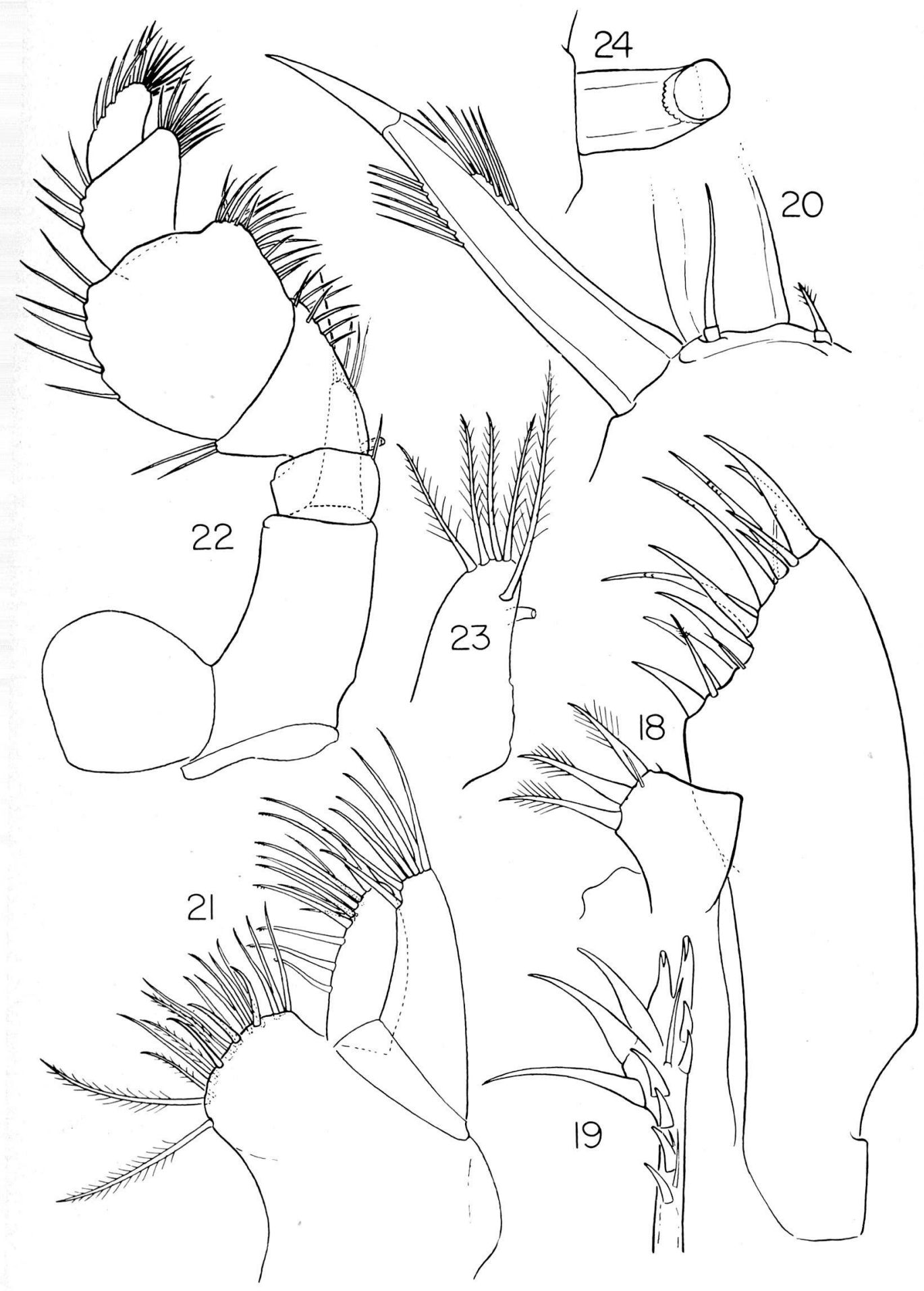




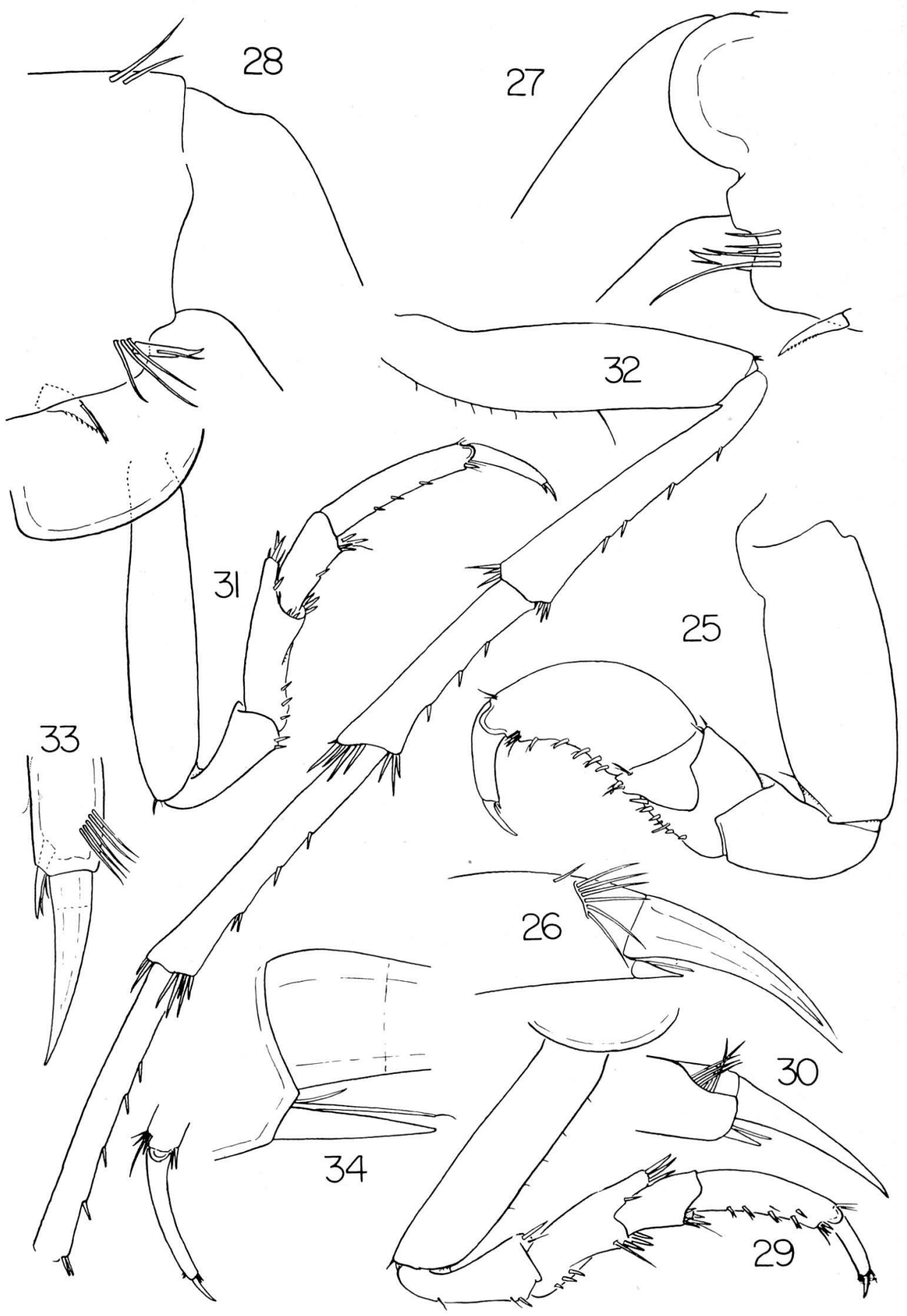




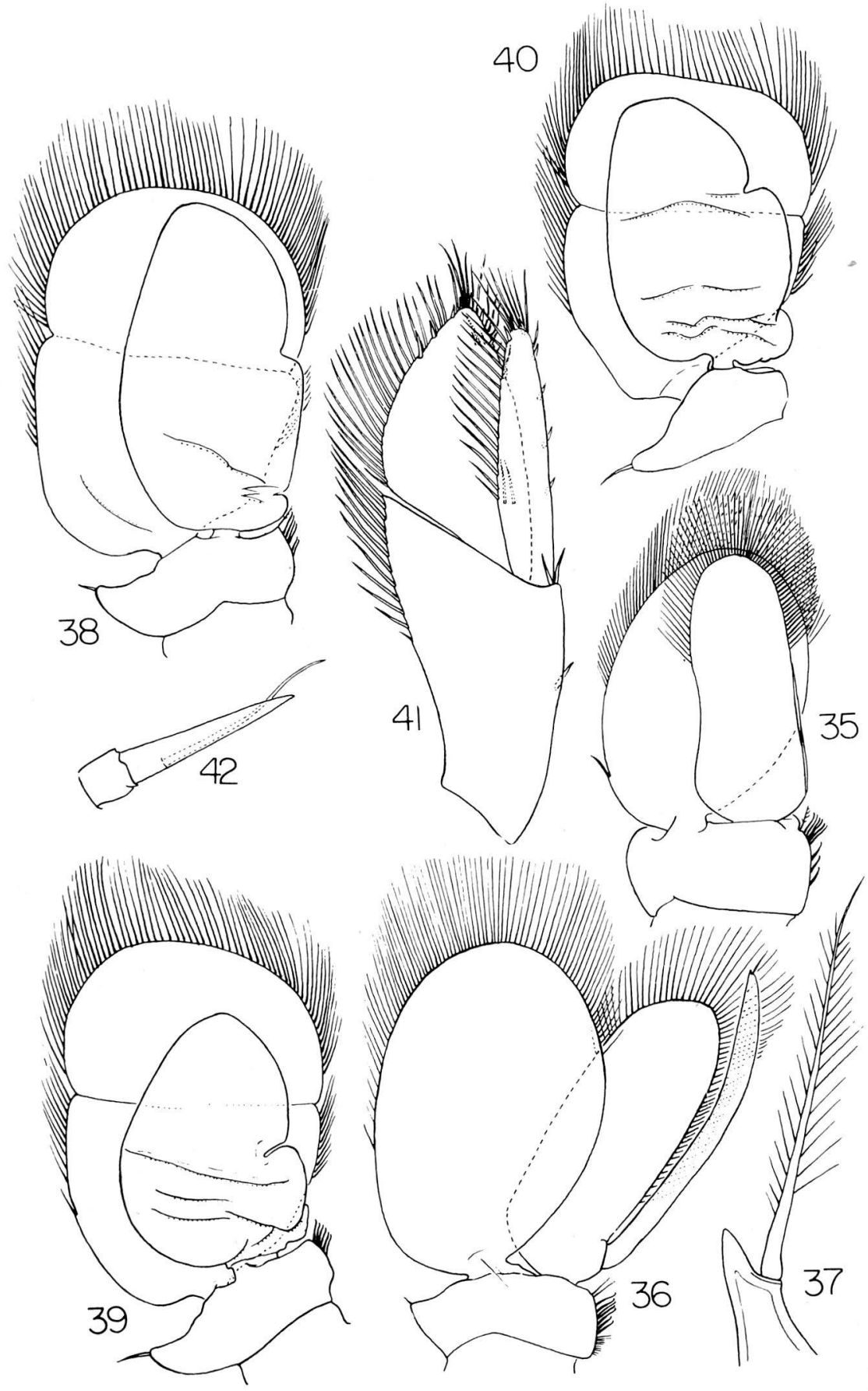




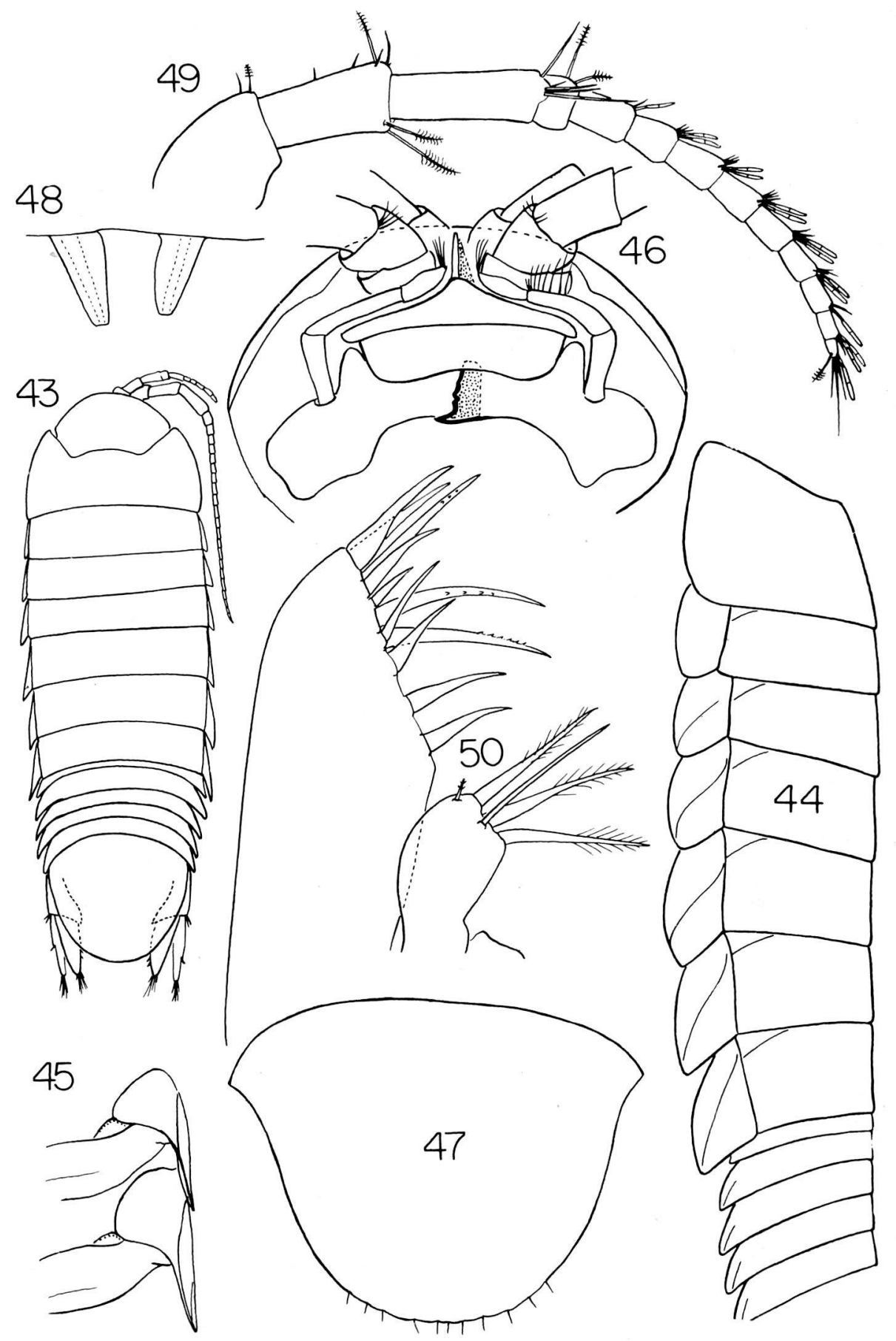




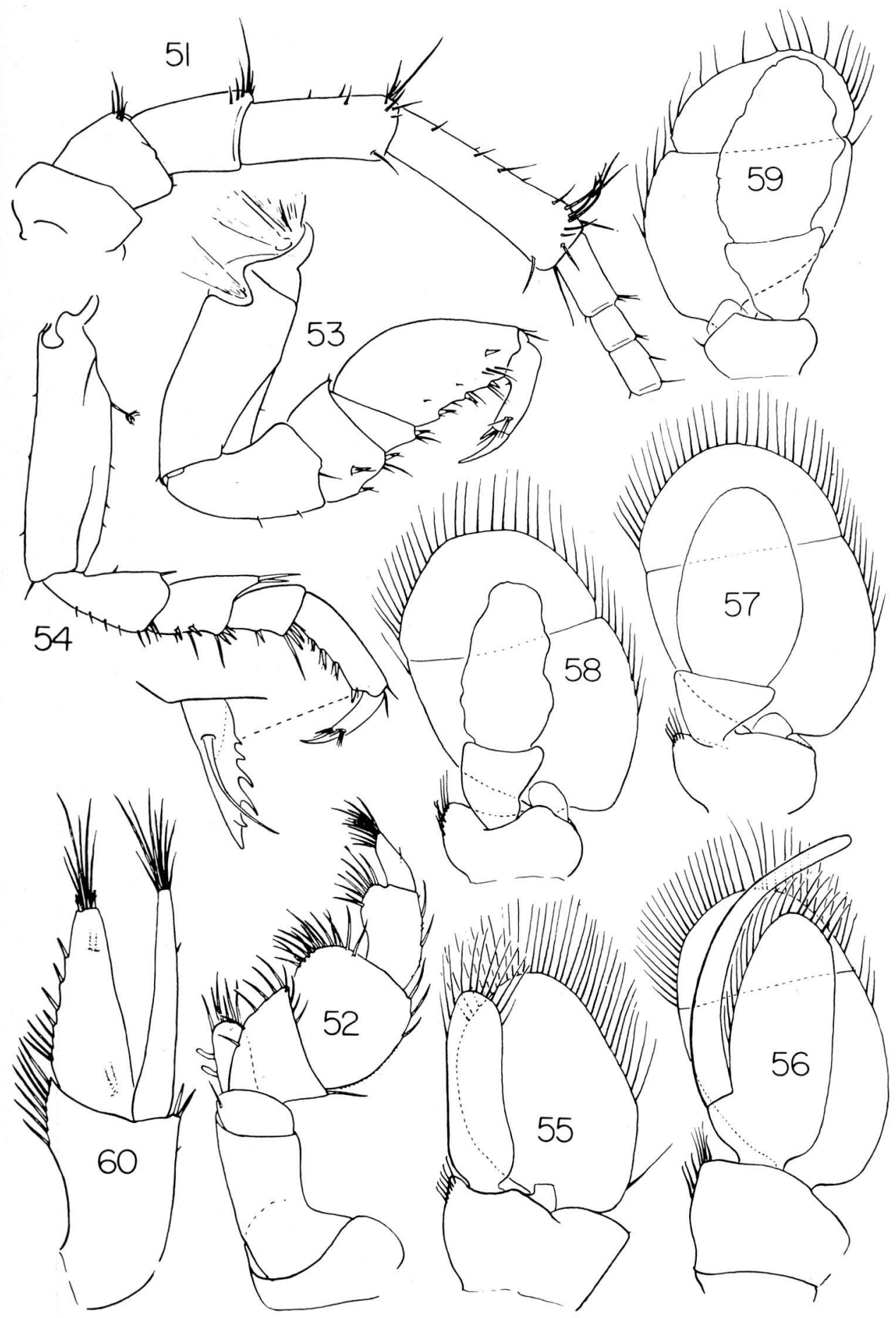




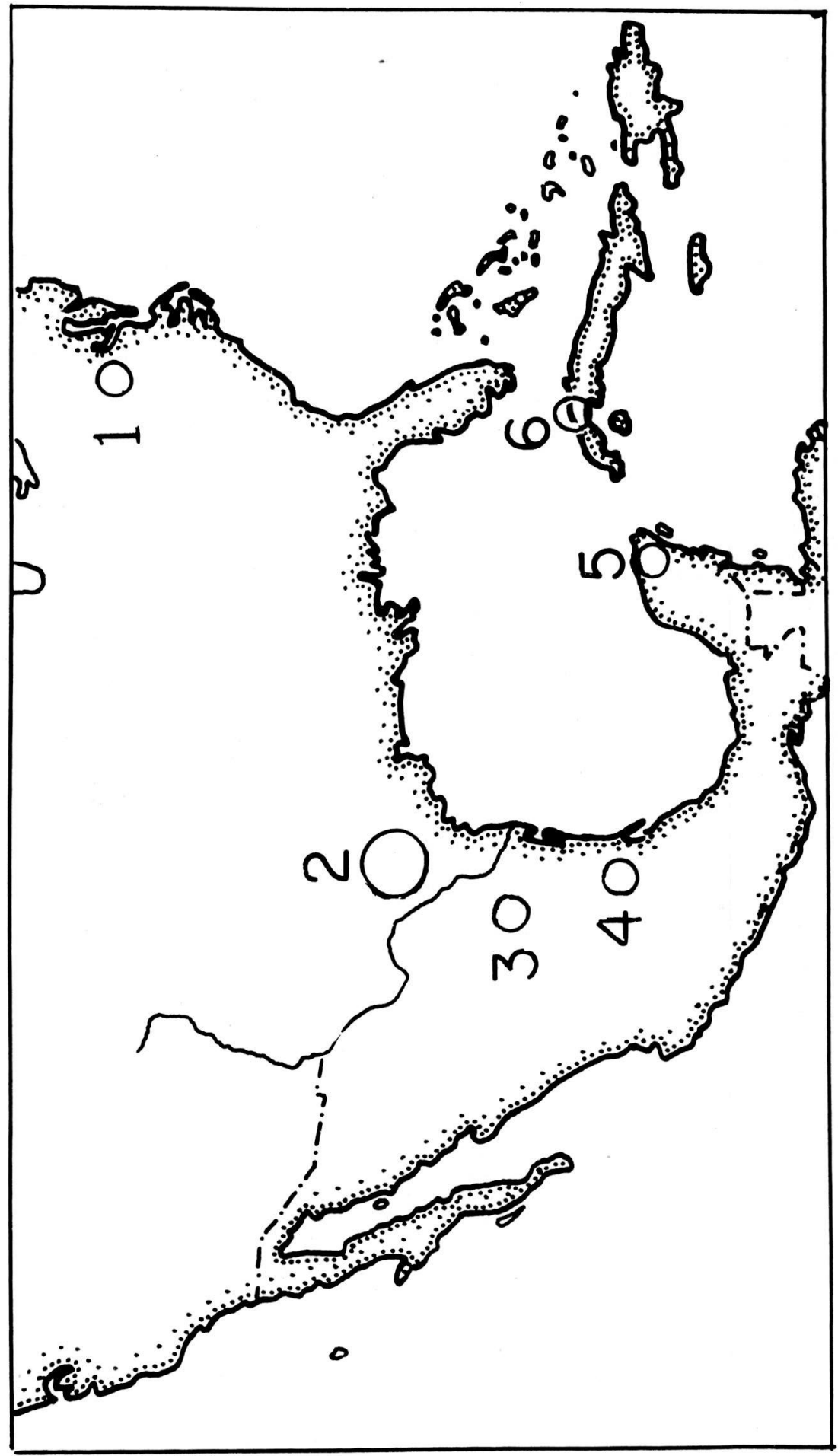

